\title{
Isotopic discrimination factors and nitrogen turnover rates in reared Atlantic bluefin tuna larvae (Thunnus thynnus): effects of maternal transmission
}

\author{
Amaya Uriarte ${ }^{1}$, Alberto García ${ }^{1}$, Aurelio Ortega ${ }^{2}$, Fernando de la Gándara ${ }^{2}$, \\ José Quintanilla ${ }^{1}$, Raúl Laiz-Carrión ${ }^{1}$ \\ ${ }^{1}$ Instituto Español de Oceanografía, Centro Oceanográfico de Málaga, Puerto Pesquero s/n, Apdo. 285, 29640 Fuengirola, \\ Málaga, Spain. E-mail: agarcia@ma.ieo.es \\ ${ }^{2}$ Instituto Español de Oceanografía, Centro Oceanográfico de Murcia, Planta de Cultivos Mazarrón, \\ Carretera de la Azohía s/n, 30860 Murcia, Spain.
}

\begin{abstract}
Summary: The use of stable isotope analysis to study animal diets requires estimates of isotopic turnover rates (half time, $\mathrm{t}_{50}$ ) and discrimination factors $(\Delta)$ for an accurate interpretation of trophic patterns. The stable isotopes of carbon and nitrogen were analysed for eggs and reared larvae of Thипnиs thynnus, as well as for the different diets supplied during the experiment. The results showed high values of $\delta^{15} \mathrm{~N}$ in eggs and larvae $(\mathrm{n}=646)$ until 4 DAH. After this time lapse, the stable isotope values declined progressively until $12 \mathrm{DAH}$, when notochord flexion began. The $\delta^{13} \mathrm{C}$ showed an inverse trend, suggesting that maternal inheritance of the stable isotopes is evident until pre-flexion stages. This study proposes a model for estimating maternal isotopic signatures of bluefin broodstock. After notochord flexion, larvae were fed with aquaculture-bred gilthead seabream, which resulted in a rapid increase of bluefin larvae $\delta^{15} \mathrm{~N}$ values together with a rapid decrease in $\delta^{13} \mathrm{C}$ values. The estimated nitrogen half-time to reach the steady state from the diet was $2.5 \pm 0.3$ days and the discrimination factor was $0.4 \pm 0.3(\% o)$. These results represent the first data set that has allowed isotopic nitrogen turnover rates and discrimination factors of the larval stages of bluefin tuna to be estimated.
\end{abstract}

Keywords: bluefin tuna larvae; stable isotopes; maternal transmission; discrimination factors; nitrogen turnover ratio.

Factores de discriminación y tasas de renovación isotópica de nitrógeno en larvas de atún rojo de cultivo (Thunnus thynnus): efectos de la transferencia materna

Resumen: El análisis de isótopos estables para estudiar la dieta de los animales requiere estimaciones de las tasas de rotación isotópicas (tiempo medio, $\mathrm{t}_{50}$ ) y factores de discriminación $(\Delta)$ para una correcta interpretación de los patrones tróficos. Los isótopos estables de carbono y nitrógeno se analizaron en los huevos y larvas criadas de Thunnus thynnus, así como para las diferentes dietas suministradas durante el experimento. Los resultados mostraron altos valores de $\delta^{15} \mathrm{~N}$ en huevos y larvas $(n=646)$ hasta cuatro días después de eclosionar. Después de este lapso de tiempo, los valores de los isótopos estables disminuyeron progresivamente hasta el día 12, cuando se inició la flexión de la notocorda. El $\delta^{13} \mathrm{C}$ mostró una tendencia inversa, lo que sugiere que la herencia materna de los isótopos estables es evidente en la etapa de pre-flexión. Este estudio propone un modelo para estimar las firmas isotópicas maternas de reproductores de atún rojo. Después de la flexión de la notocorda, las larvas se alimentaron con larvas recién eclosionadas de dorada, lo que dio lugar a un rápido aumento de los valores de $\delta^{15} \mathrm{~N}$ en las larvas de atún rojo, junto con una rápida disminución del $\delta^{13} \mathrm{C}$. El tiempo medio de nitrógeno para alcanzar el equilibrio con la dieta fue de 2,5 $\pm 0,3$ días y el factor de discriminación fue de $0,4 \pm 0,3(\%)$. Estos resultados representan el primer conjunto de datos que permitió la estimación de la tasa de renovación isotópica de nitrógeno y de los factores de discriminación en los estadios larvales de atún rojo.

Palabras clave: larvas de atún rojo; isótopos estables; transferencia materna; factores de discriminación; tasa de renovación de nitrógeno.

Citation/Como citar este artículo: Uriarte A., García A., Ortega A., de la Gándara F., Quintanilla J., Laiz-Carrión R. 2016. Isotopic discrimination factors and nitrogen turnover rates in reared Atlantic bluefin tuna larvae (Thunnus thynnus): effects of maternal transmission. Sci. Mar. 80(4): 447-456. doi: http://dx.doi.org/10.3989/scimar.04435.25A

Editor: S. Somarakis.

Received: March 4, 2016. Accepted: June 13, 2016. Published: November 3, 2016.

Copyright: () 2016 CSIC. This is an open-access article distributed under the terms of the Creative Commons Attribution (CC-by) Spain 3.0 License. 


\section{INTRODUCTION}

The large pelagic Atlantic bluefin tuna (ABFT), Thunnus thynnus (Linnaeus, 1758) is a top predator species that migrates throughout diverse types of environments, tolerating a wide range of temperatures (Block et al. 2005). The species migrates towards the Mediterranean, crossing the Strait of Gibraltar in May-June (Mather et al. 1995, Fromentin and Powers 2005), and many of the incoming bluefin find suitable spawning conditions in the oligotrophic waters of the Balearic Sea (Alemany et al. 2010, García et al. 2013).

Since the turn of the century, much research effort has been paid to bluefin due to its endangered situation; its overfishing has raised fears of population collapse among the scientific community (MacKenzie et al. 2009). Consequent with the critical situation of the resource, from 2001 to 2005 the Spanish Institute of Oceanography implemented the TUNIBAL project for ABFT larval research in their natural spawning grounds and the EU-funded SELFDOTT project (De la Gándara et al. 2012) for promoting ABFT rearing research. In view of the bluefin's critical situation, the ICCAT implemented a recovery plan for the species (ICCAT 2005).

Though the TUNIBAL field studies focused on larval feeding and growth with wild specimens within their natural habitat (Catalan et al. 2011, García et al. 2006, 2013), it was considered necessary to investigate these biological aspects from an experimental standpoint with aquaculture-reared bluefin larvae in order to interpret and adjust the field data observations. The few experimental studies based on hatchery-reared bluefin larvae address growth variability issues (Miyashita et al. 2001, Reglero et al. 2014), nutritional condition variability (Tanaka et al. 2010) and prey-dependent larval growth variability using stable isotope analysis (SIA) as food tracers (Tanaka et al. 2014).

Studies on recruitment processes of marine fish populations have long centred on the transition from yolk sac to exogenous feeding as one the most important factors that influence larval survival (Fortier and Leggett 1985, Hjort 1914, Cushing 1990). ABFT larvae are fast-growing, showing a rapid development of internal organs, including that of the digestive system (Miyashita et al. 2001, Kaji 2003, Yúfera et al. 2014). Considering the high nutritional requirements for developing fast developmental rates, some authors have suggested that the feeding shift from a planktivorous to a piscivorous diet is particularly important for survival in this species (Tanaka et al. 2014, Reglero et al. 2014).

Although it is generally thought that cannibalism may be one of the main sources of feeding success at early life stages of bluefin (Reglero et al. 2011, 2014), stomach content analysis has not been able to verify piscivory in field-captured ABFT larvae (Catalan et al. 2011). By contrast, piscivory in ABFT larvae has been observed in the Gulf of Mexico (Llopiz et al. 2010, 2014). This may be due to the fact the Balearic Sea is much more oligotrophic than the Gulf of Mexico (Laiz-Carrión et al. 2015), thus influencing the encounter rates with larval prey.
The existence of a "critical period" in the first stages of development in fish populations, specifically in the transition from yolk sac to exogenous feeding, have been highlighted by some scientists from the dawn of fisheries science (Fortier and Leggett 1985, Hjort 1914). Traditionally, trophic ecology in early life stages of marine fishes has been studied through stomach content analysis (Pepin et al. 2014). An alternative approach to understanding early life trophodynamics of larvae without examining gut contents is to estimate the natural content of the stable isotopes of nitrogen and carbon. Stable isotopes can elucidate the feeding niches of a particular species, detect their ontogenetic trophic shifts (Pepin and Dower 2007, Laiz-Carrión et al. 2013, 2015, Quintanilla et al. 2015), estimate the relative diet breadth (Sweeting et al. 2007a, 2007b, Tanaka et al. 2014) and analyse migration patterns (Rooker et al. 2007). This technique is increasingly being applied in the study of trophic food web dynamics of marine ecosystems (Bode et al. 2007, Logan et al. 2010, Costalago et al. 2012, Quintanilla et al. 2015).

This study aims at assessing the relative amount of stable isotopes of nitrogen and carbon along the ontogeny of hatchery-reared ABFT and its response to varying diets with larval development. SIA has proven to be a potential tool to study trophic ecology of wild-caught fish larvae (Laiz-Carrión et al. 2011, 2013, 2014, 2015, Quintanilla et al. 2015). But field research still needs experimental proof to understand the patterns of ontogenic-related feeding shifts and isotopic variations (Gamboa-Delgado et al. 2008, Wolf et al. 2009, Varela et al. 2011, Tanaka et al. 2014).

The use of SIA to study animal diets and trophic levels requires a priori estimates of discrimination factors $\left(\Delta^{13} \mathrm{C}, \Delta^{15} \mathrm{~N}\right)$, which form part of the isotopic composition differences between an animal and its diet (Caut et al. 2009, Martínez del Río et al. 2009, Varela et al. 2011). Previous studies have shown that these parameters depend on several sources of variation: the taxon, the development phase, its environment and the kind of tissue analysed (DeNiro and Epstein 1978, 1981, Minagawa and Wada 1984, Caut et al. 2009, Martínez del Río et al. 2009).

Rearing experiments starting at the egg stage have allowed it to be inferred that the estimated isotopic content in eggs is maternally transmitted (Hoffman et al. 2011, Le Bourg et al. 2014). The isotopic signature of maternal influence is generally conserved in yolksac stage larvae, implying that there is little or no isotopic discrimination between maternal somatic tissue and yolk-sac tissue (Hoffman et al. 2011). The biological importance of maternal transmission is paramount for larval survival as it transfers nutritional and immunological conditions to offspring (Swain and Nayak 2009, Perez and Fuiman 2015).

Very few studies have examined the discrimination factors in adults (Madigan et al. 2012) and tuna juveniles (Varela et al. 2011), but the lack information in larval stages is very limited, since there is no existing specific SIA rearing experience in ABFT larvae. In order to fill this gap, the aim of this experiment was to estimate isotopic discrimination factors and turnover 
ratio during ontogeny development until early juvenile stages of reared ABFT and to propose a model for predicting the isotopic signatures of maternal origin.

\section{MATERIALS AND METHODS}

\section{Experiment design and sampling}

Fertilized eggs of ABFT were obtained on 24 June 2013 from a spontaneous spawning of broodstock in the farming facilities at El Gorguel, Cartagena (SE Spain), of the Caladeros del Mediterráneo Company. The fertilized eggs were transferred to facilities of the Spanish Institute of Oceanography (IEO) in Mazarrón (SE Spain). An experimental rearing was undertaken with 50000 ABFT larvae. Larvae 2 days after hatching (DAH) were placed in a 5000-L tank. Larvae were fed on rotifers from the beginning to $18 \mathrm{DAH}$. Artemia salina was also supplied to larvae from 16 to $20 \mathrm{DAH}$. A piscivorous diet was started on $17 \mathrm{DAH}$, consisting of yolk-sac larvae of gilthead seabream (Sparus aurata), and between 17 and $20 \mathrm{DAH}$ both types of diets were used to feed ABFT larvae.

The water temperature throughout the experiment was $24^{\circ} \mathrm{C}$ on average. The light regime was 14 hours per day and intensity was between 500 and 800 lx. The larval rearing experience followed the methodology described by Ortega et al. (2011) and De la Gándara et al. (2012). The experiment was performed according to Spanish law 6/2013 based on the European Union directive on animal welfare (Directive 2010/63/EU on the protection of animals used for scientific purposes).

ABFT eggs and hatched larvae were collected regularly every 2 days until $15 \mathrm{DAH}$. After this period, larvae were sampled every 3 days until $32 \mathrm{DAH}$. The larvae were anaesthetized using $100-200 \mathrm{mg} \mathrm{l}^{-1}$ MS222 (tricaine methane sulfonate, Sigma-Aldrich, USA) depending on fish size. ABFT larvae and preys were immediately conserved in a $-80^{\circ} \mathrm{C}$ freezer until laboratory analysis. The samples of ABFT larvae were measured for standard length (SL) with the Image-Pro Analysis Software. Afterwards, samples were dehydrated in a freeze dryer for $24 \mathrm{~h}$ and weighed with a precision microbalance $(0.01 \mathrm{mg})$ for quantifying the relative composition of nitrogen and carbon isotopes.

\section{Stable isotope analysis}

Egg and larval samples were pooled for each age class until $6 \mathrm{DAH}$ in order to reach the required dry weight (DW) for SIA analysis (1-2 mg). The larvae from 8 to $32 \mathrm{DAH}$ were individually analysed. For SIA, aliquots of 7-10 replicates for each age class were analysed. The ABFT and prey samples were homogenized and packed in tin capsules after dry freezing. The content of ${ }^{13} \mathrm{C}$ and ${ }^{15} \mathrm{~N}$ was measured by continuous gas flow system using a Thermo Finnigan Elementary Analyzer Flash EA 1112 coupled to a Finnigan MAT Delta Plus mass spectrometer at the Instrumental unit of Analysis of the University or A Coruña. Ratios of ${ }^{15} \mathrm{~N} /{ }^{14} \mathrm{~N}$ and ${ }^{13} \mathrm{C} /{ }^{12} \mathrm{C}$ were expressed in conventional delta notation $(\delta)$, relative to the international standard, atmospheric air $\left(\mathrm{N}_{2}\right)$ and Vienna Pee Dee Belemnite, respectively, using acetanilide as standard. The relative abundances of ${ }^{13} \mathrm{C}$ and ${ }^{15} \mathrm{~N}$ were reported as isotopic ratios (parts per thousand, \%o) relative to standards.

For carbon SIA, a previous chemical extraction of lipids is required. This analytical procedure could not be carried out due to the low larval weight. Nevertheless, a posterior correction of the $\delta^{13} \mathrm{C}$ values for lipid content in ABFT larvae and preys was estimated using the model proposed by Logan et al. (2008). This empirical lipid correction has been previously used in fish larvae (Laiz-Carrión et al. 2013, 2015, Quintanilla et al. 2015).

\section{Discrimination factors}

The discrimination factor $(\Delta)$ of stable isotopes is the difference in the isotopic composition between the animal and its food source (Caut et al. 2009). This factor is influenced by the maternal isotopic signature in early life stages $\left(\delta X_{\text {mother }}=\delta X_{\text {egg }}\right)$, since isotopic values of eggs and endogenous feeding larvae are totally determined by maternal transfer (Le Bourg et al. 2014). Therefore, this study estimated the isotopic discrimination factor by maternal transference in pre-flexion larvae, through Equation (1):

$$
\Delta \mathrm{X}_{\text {mother }}=\delta \mathrm{X}_{\text {pre-flexion }}-\delta \mathrm{X}_{\mathrm{egg}}
$$

where $\delta \mathrm{X}$ represents the stable isotopic ratio (carbon or nitrogen) of ABFT eggs and pre-flexion larvae. The carbon and nitrogen stable isotopic ratio discrimination for maternal transference $\left(\Delta X_{m}\right)$ was estimated by the difference between the isotopic values of eggs and the pre-flexion larvae.

The estimated isotopic signature of maternal origin was calculated by solving Equation (2):

$$
\delta \mathrm{X}_{\text {mother }}=\delta \mathrm{X}_{\text {pre-flexion }}-\left(\Delta \mathrm{X}_{\text {mother }} * \mathrm{SL}_{\text {pre-flexion }}\right)
$$

where $\delta \mathrm{X}_{\text {mother }}$ represents the stable isotopic ratio (carbon or nitrogen) of maternal origin through SL of preflexion larvae.

The discrimination factor by diet $(\Delta X)$ of reared post-flexion ABFT larvae was calculated when reaching steady state (24-32 DAH) with the diet, through Equation (3):

$$
\Delta \mathrm{X}_{\text {diet }}=\delta \mathrm{X}_{\text {post-flexion }}-\delta \mathrm{X}_{\text {prey }}
$$

where $\delta \mathrm{X}$ represents the stable isotopic ratio (carbon or nitrogen) of the ABFT post-flexion larvae and $\delta \mathrm{X}_{\text {prey }}$ corresponds to the isotopic ratio of seabream yolk-sac larvae.

\section{Estimation of nitrogen turnover rate and half time}

Nitrogen turnover rate was calculated in ABFT post-flexion larvae after diet transition over time until steady state was established between the larvae and its diet. These values were fitted to an exponential model (Eq. 4). The model was first applied by Hesslein et al. 
(1993) to tissue changes in larval whitefish (Coregonus nasus) and later by Gamboa-Delgado et al. (2008) to larvae of Solea senegalensis and by Tanaka et al. (2010) to larvae of Thunnus orientalis. The model integrates isotopic values with time, as well as their growth and metabolic rates through Equation (4):

$$
\delta \mathrm{N}_{\text {larvae }}=\delta \mathrm{N}_{\mathrm{n}}+\left(\delta \mathrm{N}_{\mathrm{o}}-\delta \mathrm{N}_{\mathrm{n}}\right) \mathrm{e}^{-(k+m)}
$$

where $\mathrm{N}_{\text {larvae }}$ is nitrogen isotopic value of larvae (whole body mass) at time $t$,

$\mathrm{N}_{\mathrm{o}}$ is the nitrogen isotopic value of each larva in steady state with the initial diet,

$\mathrm{N}_{\mathrm{n}}$ is the isotopic value reached when the larvae is in equilibrium with a new diet,

$k$ is the growth rate expressed per day $\left(\mathrm{d}^{-1}\right)$, and $m$ is the metabolic turnover rate $\left(\mathrm{d}^{-1}\right)$ that is derived from Equation 4 (Hesslein et al. 1993).

An estimate of the growth rate was derived from the exponential growth equation for weight (Eq. 5)

$$
\mathrm{W}=\mathrm{W}_{0} * \mathrm{e}^{(k * t)}
$$

where $\mathrm{W}$ is the final $\mathrm{DW}, \mathrm{W}_{0}$ is the initial weight and $t$ is the time (days).

Turnover rates can be measured by monitoring larval isotopic values over time until a steady state between larvae and their diet is reached. A function is then fitted to the change in isotopic composition over time, and can provide an estimation of the time necessary for half of the larvae to reach isotopic steady state after consuming a new diet. The half-life for nitrogen isotopes in post-flexion BFT larvae can be calculated (half time, $\mathrm{t}_{50}$ ) (Eq. 6):

$$
\mathrm{t}_{50}=\operatorname{Ln} 2 /(m+k)
$$

where $t_{50}$ is the half-life time of isotopic incorporation into larval tissue, and $m$ and $k$ correspond to variables cited above.

\section{Statistical analysis}

The Kruskal-Wallis test was applied to analyse the statistical differences of isotopic values of $\delta^{15} \mathrm{~N}$ and $\delta^{13} \mathrm{C}$ during ontogenetic development until the early juvenile phase of ABFT when the isotopic discrimination factor reached isotopic steady state with prey. The maternal influence was estimated through to the linear correlation of the isotopic values of pre-flexion larvae minus the isotopic values of the eggs. All statistical tests were undertaken using the STATISTICAL 7.0 package (Statsoft) and the significance level for all analyses was set at $\alpha=0.05$.

\section{RESULTS}

\section{Larval growth}

A total of 115 samples from reared ABFT were analysed to estimate the SIA values $\left(\delta^{15} \mathrm{~N}, \delta^{13} \mathrm{C}\right)$ in this experimental study, starting from the egg stage $(-1$

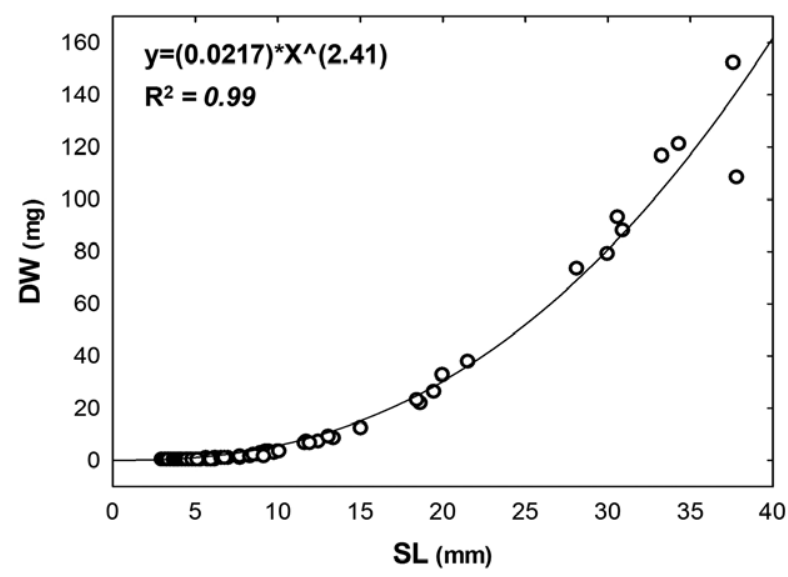

Fig 1. - Relationship between SL and DW of ABFT larvae.

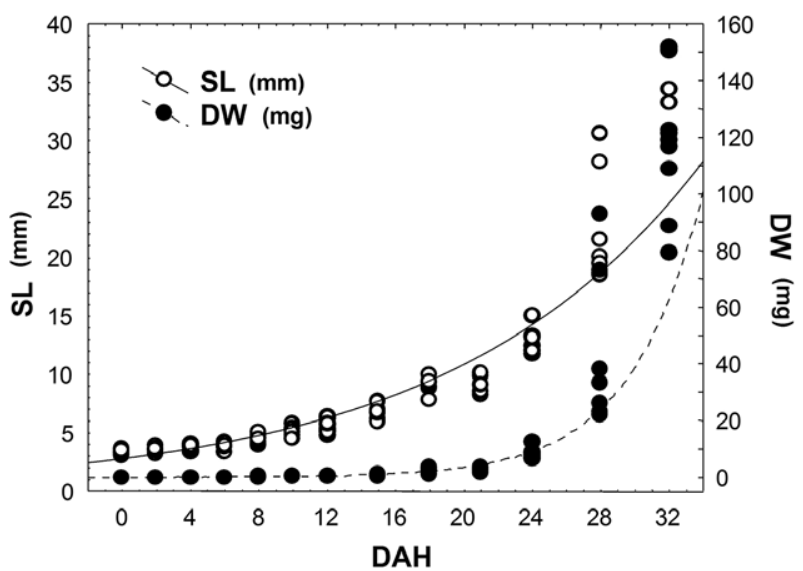

Fig 2. - Relationship of SL and DW with DAH of ABFT larvae. Closed and open circles indicate DW and SL, respectively.

DAH) $(n=10$ pooled), to pre-flexion larvae (0-6 DAH, $\mathrm{n}=35$ pooled; $6-12$ DAH, $\mathrm{n}=28$ larvae) and to post-flexion (15 DAH, $n=42$ larvae). The newly hatched larvae measured on average $3.5 \pm 0.23 \mathrm{~mm}$ SL and their mean DW was $0.07 \pm 0.00 \mathrm{mg}$. Yolk sacs of the larvae were fully consumed at $2 \mathrm{DAH}$. The relative growth relationship indicates slow growth during the pre-flexion phase (0-10 DAH) (Fig. 1). The notochord flexion started at $15 \mathrm{DAH}$, when larvae ranged between 5.5 and $6.5 \mathrm{~mm}$ SL. After $22 \mathrm{DAH}$, larvae showed fast growth in length and an exponential increase in weight with age (Fig. 2).

\section{Isotopic variation}

The isotopic composition of carbon and nitrogen showed differences during larval development throughout the rearing experiment (Kruskal-Wallis $\mathrm{p}<0.01$ ) (Fig. 3), from the egg $(-1)$ to $32 \mathrm{DAH}$. The stable isotopes of nitrogen and carbon ranged from $5.0 \%$ o to $14.3 \%$ o for $\delta^{15} \mathrm{~N}$ and from $-18.9 \%$ o to $-12.1 \%$ o for $\delta^{13} \mathrm{C}$

Maximum $\delta^{15} \mathrm{~N}$ values were found in the egg and yolk-sac stages, where $\delta^{15} \mathrm{~N}$ values averaged $12.6 \pm 1.0 \%$ ( $n=40)$, (Fig. 3). Thereafter, $\delta^{15} \mathrm{~N}$ showed a decreasing trend during the early stages of development until minimum values were reached at $15 \mathrm{DAH}$, 


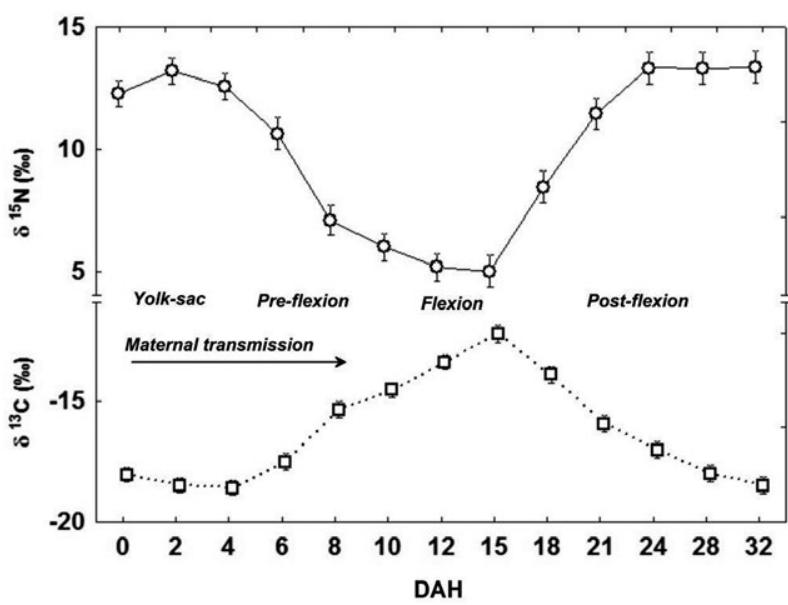

Fig 3. - Values of $\delta^{15} \mathrm{~N}$ and $\delta^{13} \mathrm{C}$ ABFT larvae during the ontogenic evolution of the experiment. Vertical lines indicate \pm SD $(n=115)$.

Closed and open circles indicate $\delta^{13} \mathrm{C}$ and $\delta^{15} \mathrm{~N}$, respectively.

coinciding with the initiation of notochord flexion. At $15 \mathrm{DAH}, 85 \%$ of the larvae showed notochord flexion, corresponding to the lowest isotopic values of nitrogen $\left(5.0 \pm 0.11 \%\right.$ ) . After flexion, $\delta^{15} \mathrm{~N}$ values increased as larvae developed into early juveniles. From 24 to $32 \mathrm{DAH}, \delta^{15} \mathrm{~N}$ values were stabilized at $13 \pm 0.34 \%$ (Fig. 3).

The isotopic composition of carbon showed an inverse trend to that of the stable isotope of nitrogen (Fig. 3 ). The lowest $\delta^{13} \mathrm{C}$ values coincided with the egg and yolk-sac stages. Thereafter, the carbon stable isotope increased steadily until $15 \mathrm{DAH}$, when the highest $\delta^{13} \mathrm{C}$ values were recorded $\left(-12.3 \pm 0.1 \%\right.$ ). Afterwards, $\delta^{13} \mathrm{C}$ values decreased steadily. Unlike the values of $\delta^{15} \mathrm{~N}$, those of $\delta^{13} \mathrm{C}$ did not reach a point of steady state between 24 to 32 DAH.

Our results showed the variation of the isotopic values during the three stages of larval development of ABFT (Fig. 3). We observed significant differences between different larval developmental stages, particularly between pre-flexion and flexion (KruskalWallis, $\mathrm{p}<0.05)$, and between flexion and post-flexion (Kruskal-Wallis, $\mathrm{p}<0.05$ ). Nonetheless, nitrogen and carbon isotopic values of the pre-flexion phase, containing isotopes of maternal origin, did not differ significantly from those of the ensuing post-flexion developmental phase (Kruskal-Wallis, $\mathrm{p}>0.05$ ), owing to the high isotopic signature of the seabream yolk-sac larvae supplied as preys.

\section{Pre-flexion discrimination factors}

The highest $\delta^{15} \mathrm{~N}$ and lowest $\delta^{13} \mathrm{C}$ values were observed in the eggs (-1 DAH) and the early pre-flexion larvae (0-4 DAH). The stable isotopes followed a timeline pattern with ontogeny. Therefore, it is logical to

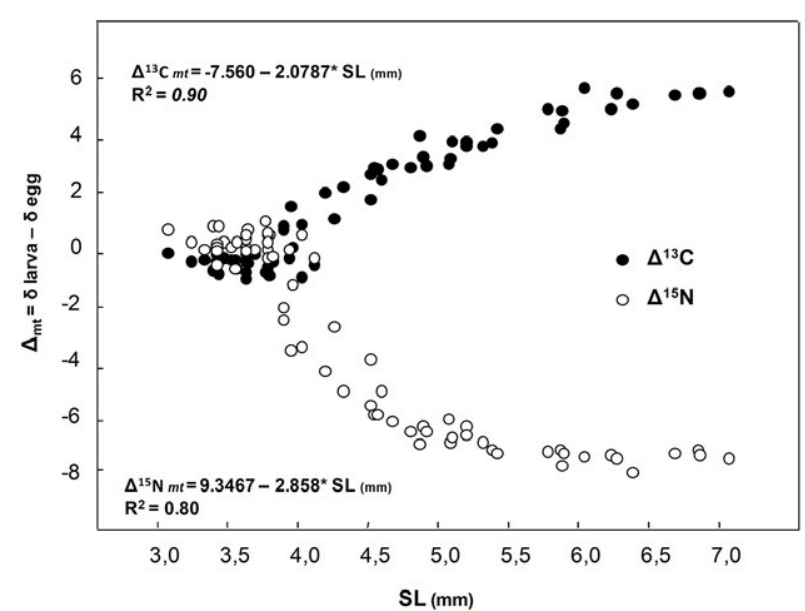

Fig 4. - Correlation by discrimination factors $(\Delta)$ vs SL in pre-flexion ABFT larvae (0-15 DAH). Closed and open circles indicate $\Delta^{13} \mathrm{C}$ and $\Delta^{15} \mathrm{~N}$, respectively.

assume that the initial values of stable isotopes correspond to maternal transmission.

While $\delta^{15} \mathrm{~N}$ started off with the peak values at the egg stage, $\delta^{13} \mathrm{C}$ values started at minimum levels. Both stable isotopes reached their turning point at $15 \mathrm{DAH}$ (Fig. 3), coinciding with the initiation of notochord flexion.

The isotopic discrimination factors and turnover ratios could not be estimated in pre-flexion larvae, because the larvae did not attain a steady state with their diet. Moreover, isotopic signatures at early larval stages were connected to maternal transmission, whose isotopic nitrogen and carbon showed significant linear correlations with growth in length (SL) of the reared ABFT larvae until 15 DAH (Fig. 4).

By solving this relationship, it was feasible to estimate the amount of maternally transmitted stable isotopes of nitrogen and carbon, taking into account the distribution of larval sizes (SL) of pre-flexion larvae. The estimated isotopic composition of maternal origin did not differ significantly from the values of stable isotopes recorded in the egg stage (Kruskal-Wallis, $\mathrm{p}>0.05$ ). Based on the proposed model, the maternally transmitted isotopic signatures $\left(\delta^{15} \mathrm{~N}, \delta^{13} \mathrm{C}\right)$ can be predicted from the preflexion (SL) larvae of ABFT (Table 1).

\section{Post-flexion discrimination factors}

At 17 DAH, ABFT larvae started feeding on gilthead seabream yolk-sac larvae. This larval prey had high nitrogen isotopic values $\left(\delta^{15} \mathrm{~N} \quad 12.91 \pm 0.13 \%\right.$ ) and low carbon isotopic values $\left(\delta^{13} \mathrm{C}-20.90 \pm 0.32 \% 0\right)$. Therefore, the isotopic values of post-flexion ABFT larvae showed a significant increase in nitrogen and a decrease in carbon $(\mathrm{p}<0.05$, Kruskal-Wallis). The final phase of the experiment (24-32 DAH) showed

Table 1. - Model for predicting the isotopic signatures of nitrogen and carbon of maternal origin using the SL (mm) of pre-flexion ABFT larvae. NS, non-significant, Kruskal-Wallis ( $>0.05)$ between measured egg isotopic values and the estimate of the model (mean \pm SD).

\begin{tabular}{ccccc}
\hline \multicolumn{2}{c}{$\begin{array}{c}\text { Model for predicting maternally transmitted } \delta X_{m} \\
\text { using length }(\mathrm{SL})(\mathrm{n}=72)\end{array}$} & $\mathrm{R}^{2}$ & $\begin{array}{c}\delta X_{\mathrm{m}} \\
\text { Estimated }(\mathrm{n}=72)\end{array}$ & $\begin{array}{c}\delta \mathrm{X}_{\mathrm{m}} \\
\text { Egg value }(\mathrm{n}=10)\end{array}$ \\
\hline$\delta^{15} \mathrm{~N}(\%)=$ & $\delta^{15} \mathrm{~N}_{\text {larva }}+\left(9,3467+2,858 *\right.$ length $\left._{(\mathrm{mm})}\right)$ & 0.80 & $12.35 \pm 1.50$ & $12.30 \pm 0.04$ \\
$\delta^{13} \mathrm{C}(\%)=$ & $\delta^{13} \mathrm{C}_{\text {larva }}+\left(-7,560-2,0787 *\right.$ length $\left._{(\mathrm{mm})}\right)$ & 0.90 & $-17.78 \pm 0.74$ & $\mathrm{NS}$ \\
\hline
\end{tabular}




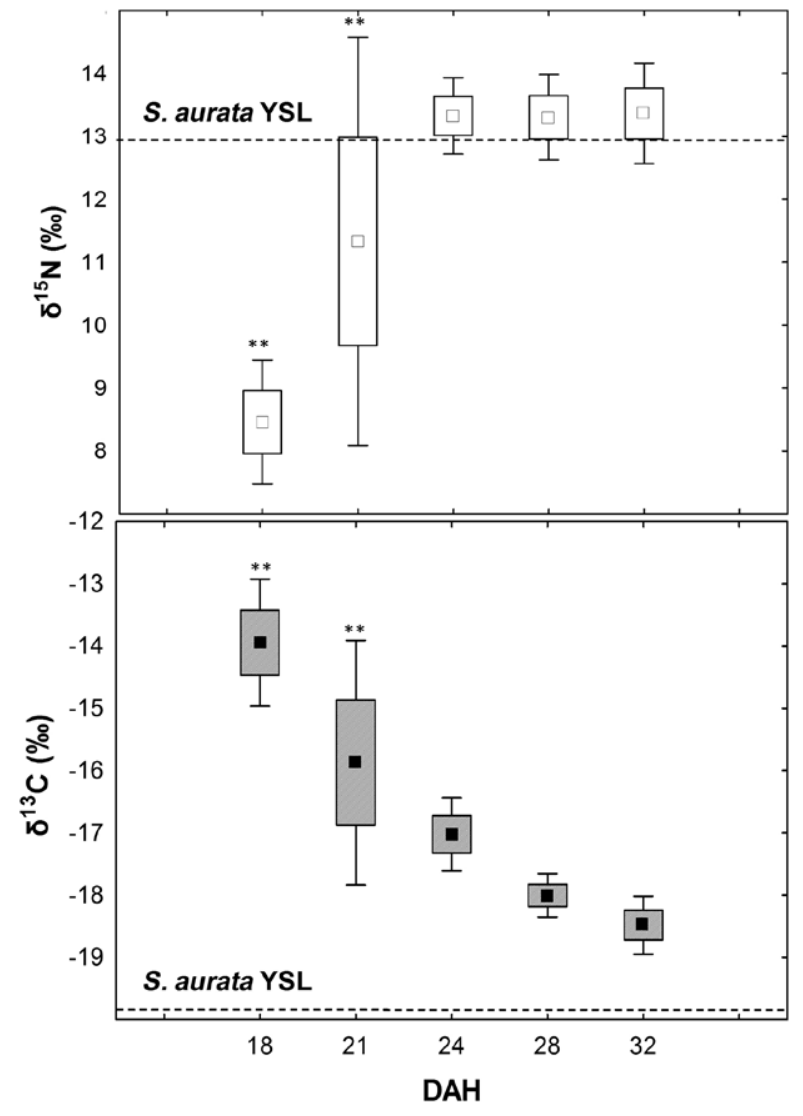

Fig. 5. - Changes in mean $\delta^{15} \mathrm{~N}$ and $\delta^{13} \mathrm{C}$ of ABFT larvae from 18 to 32 DAH. White and black squares indicate $\delta^{13} \mathrm{C}$ and $\delta^{15} \mathrm{~N}$, respectively. Error vertical bars shows the standard deviation and the black horizontal line indicate $\Delta^{13} \mathrm{C}$ and $\Delta^{15} \mathrm{~N}$ between mean isotopic values. $* *$ indicates significantly different at $\mathrm{P}<0.001$ (Kruskal-Wallis test).

isotopic values in a similar range to the initial values recorded at the early stages $\left(\delta^{15} \mathrm{~N} 13.30 \pm 0.35 \%\right.$ and $\delta^{13} \mathrm{C}-18.01 \pm 0.18 \%$, respectively). Between 24 and 32 DAH, ABFT larvae reached the isotopic steady state of nitrogen with their diet. The discrimination factor estimated during this period was $0.4 \%$. By contrast, $\delta^{13} \mathrm{C}$ values did not attain the isotopic steady state with the diet (Fig. 5).

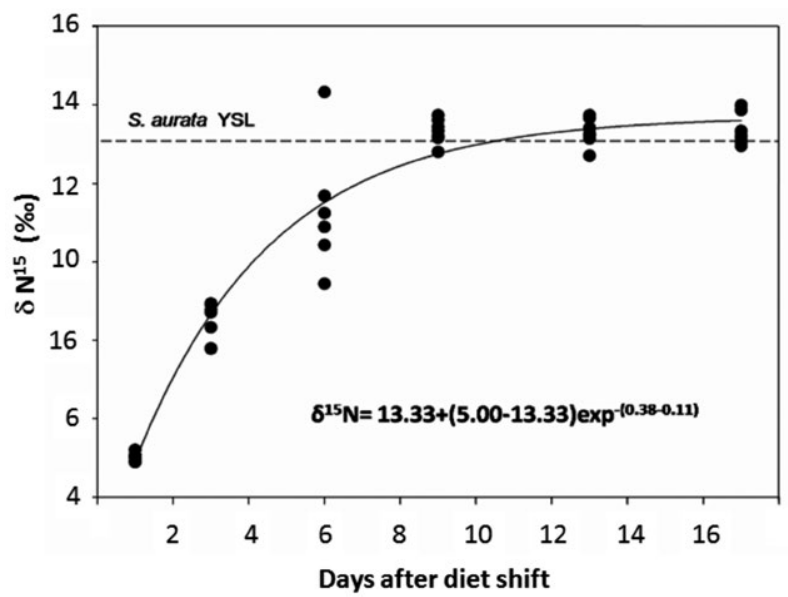

Fig 6. - Values of $\delta^{15} \mathrm{~N}$ in post-flexion ABFT larvae after a diet shift at 15 DAH when the Artemia diet changes to yolk sac larvae of gilthead seabream (dashed line indicate $\delta^{15} \mathrm{~N}$ of seabream).

\section{Estimation of nitrogen turnover rate and half time}

The $\delta^{15} \mathrm{~N}$ values of the post-flexion larvae changed rapidly when their diet switched to gilthead seabream yolk-sac larvae. These values increased until the asymptotic value of the prey $(12.94 \pm 0.13 \%$ o $)$ was reached, which occurred 9 days after the start of feeding on yolk-sac larvae (Fig. 6). The estimated nitrogen turnover rate (half-time, $\mathrm{t}_{50}$ ) was $2.49 \pm 0.28$ days and the constant $m$ was negative in post-flexion larvae $(-0.11)$. The exponential model showed a good fit for DW, evidencing fast body mass growth $(k=0.38)$.

\section{DISCUSSION}

SIA studies are used extensively to assess the biochemical tracers of the trophic flow between different trophic positions of the food web (Peterson and Fry 1987, Vander Zanden and Rasmussen 2001, Post 2002, Bode et al. 2007, Pepin and Dower 2007). Nonetheless, the analysis of isotopic discrimination factors and turnover ratios under controlled experimental conditions provides essential information for understanding the physiological aspects affecting the species and their development (Gannes et al. 1997, Kiyoko et al. 2008, Wolf et al. 2009). The application of SIA in field-captured larvae of commercially important species, such as tunas, indicates the need for experimental research to disentangle the related physiological processes involved during larval development and to enable field-derived estimates of nitrogen and carbon stable isotopes to be interpreted (Laiz-Carrión et al. 2014, 2015).

\section{Larval growth}

From the ecological point of view, larval growth rates are paramount to survival, as postulated by the growth mortality hypothesis (Houde et al. 1987, Anderson 1988). Larval survival is directly related to recruitment and may therefore have important fisheries management implications. The faster growth in the ABFT larvae may be largely responsible for the most successful year class (2003) during the past years (García et al. 2013, Suzuki et al. 2013). The relationship of ABFT larval growth and survival was also evidenced in Pacific ABFT larvae and juveniles (Tanaka et al. 2006, Satoh et al. 2013).

Studies of trophic ecology in early life stages of fish highlight the existence of a "critical period" in the transition from yolk-sac to exogenous feeding as one of the most important factors affecting larval survival (Fortier and Leggett 1985). Growth in this time interval is slow, and larval mortalities are high under rearing conditions (Kaji 2003). Fast growth occurs after notochord flexion, increasing significantly during the last phase of experimental study (15 to $32 \mathrm{DAH}$ ) (Figs 1 and 2). Overall, those larvae with $32 \mathrm{DAH}$ reached an average of $45 \mathrm{~mm} \mathrm{SL}$ and $265 \mathrm{mg}$ DW, slightly lower than the values reported by Yúfera et al. (2014), but higher than those reported by Miyashita et al. (2001) for the Pacific BFT (Thunnus orientalis). The growth observed from reared larvae is consistent with the estimated growth of 
field-captured ABFT (García et al. 2013), despite the fact that the field larvae were conserved in liquid $\mathrm{N}$ preserved specimens, whose shrinkage was not taken into account. However, this conservation agent (liquid nitrogen conserved larvae and sea water) accounted for the least shrinkage in sardine larvae (6\% of total SL) (García et al. 2004). Thus, due to the more robust morphological larval characteristics of ABFT larvae, the age-length key of larval tuna from the field (García et al. 2013) does not differ significantly from that of reared tuna. In the field, ABFT size at post-flexion was at $5.5 \mathrm{~mm}$, and considering that Itoh et al. (2000) observed the non-deposition of daily increments for a period of $4 \mathrm{DAH}$, both growth models are in agreement.

\section{Isotopic variation}

The supply of different diets or preys to reared fishes can have important consequences on growth variability (Gamboa-Delgado et al. 2008, Tanaka et al. 2010, 2014). Under rearing conditions, the trophic shift from planktivory to piscivory is crucial for larval growth (Reglero et al. 2014). At the end of the flexion stage, ABFT larvae need to predate on larger and faster preys (Ortega et al. 2011). In this experiment, the piscivorous diet began at $17 \mathrm{DAH}$ and the survival after this phase was $1.5 \%$ at $21 \mathrm{DAH}$. At this stage, the maternal isotopic signatures are not evidenced because the isotopic composition of the prey is incorporated in the larval tissues (see Fig. 3). It is during this critical period of trophic diet change that the first signs of gastric glands appear, initiating the formation of the digestive system (Kaji 2003, Yúfera et al. 2014). Consequently, the growth hormone increases together with the increase in somatic mass (Kaji et al. 1999, Kaji 2003).

Tanaka et al. (2014) carried out an isotopic study that analysed two different larval diets using stable isotopes as nutritional tracers from the flexion stage to early juveniles in Pacific BFT (Thunnus orientalis). The feeding regime consisted of a group fed with rotifers and another group fed with yolk-sac larvae of the spangled emperor fish (Lethrinus nebulosus) at 15 DAH. The fish-fed group showed significantly higher growth than the rotifer-fed group. Therefore, the $\delta^{15} \mathrm{~N}$ values increased exponentially with DAH while those of the rotifer-fed group remained at low $\delta^{15} \mathrm{~N}$ levels, demonstrating that nutritional quality can enhance larval growth and, ultimately, larval survival.

The maternal isotopic ratios observed in the initial stages of larval development open the possibility of estimating the nutritional tracers of mature females from field-collected eggs and from the initial stages of larval development. Maternal qualities related to condition may be relevant to growth potential of larvae (Marteinsdottir and Steinarsson 1998, Green and McCormick 2005, Swain and Nayak 2009, Perez and Fuiman 2015). Under natural conditions, higher values of $\delta^{15} \mathrm{~N}$ have shown greater growth potential in bullet tuna larvae (Auxis rochei) and in the Mediterranean anchovy (Engraulis encrasicolus) (Laiz-Carrión et al. 2011, Quintanilla et al. 2015). Thus, it is reasonable to assume that isotopic values of mother-offspring pro- vide relevant information on the trophic position of the broodstock and may reflect larval growth characteristics as well as migratory patterns between populations (Hoffman et al. 2011, Le Bourg et al. 2014).

\section{Pre-flexion discrimination factors}

It is at this initial stage of larval development when the isotopic signatures of maternal transmission predominate. At this stage, larval mortality is high because food intake does not fully compensate for the somatic growth rates that lead to the gradual decline of the isotopic ratios. The role of maternal influence is preponderant for bearing healthy offspring where quality seed depends on the state of maternal nutrition (Swain and Nayak 2009, Perez and Fuiman 2015). The maternal nutritional condition showed important links with the development of survival skills developed by reared larvae of red drum (Scienops ocellatus) (Perez and Fuiman 2015). Furthermore, progeny of certain species, such as, those belonging to the family of salmonids can inherit maternal isotopic signatures depending on the spawning habitat in which these were spawned (Jardine et al. 2008).

In regard to isotopic studies, little or no isotopic discrimination between maternal somatic tissue and yolk-sac tissue has been shown (Le Bourg et al. 2014, Hoffman et al. 2011). In aplacental deep-sea sharks, small differences between mothers and their embryos were observed in the values of $\delta^{15} \mathrm{~N}$ and $\delta^{13} \mathrm{C}$, proving that shark embryos reflect the same trophic position as their mothers (McMeans et al. 2009, Vaudo et al. 2010).

The signatures of stable isotope of nitrogen in wild adult ABFT spawners from the Mediterranean reported in scientific literature are in the order of those estimated by egg and pre-flexion larvae $(10.89 \pm 0.95 \%$ o for wildcaught tuna and $11.83 \pm 0.28 \%$ o for cage-reared tuna) (Varela et al. 2011). However, Estrada et al. (2005) found high values of $\delta^{15} \mathrm{~N}$, which reached $14 \%$ in adult ABFT from the Gulf of Maine. In the present experimental study, fertilized ABFT eggs collected from tuna fattening cages showed $\delta^{15} \mathrm{~N}$ values of $12.35 \pm 0.04 \%$. Being able to estimate the maternal isotopic signatures from early life larval stages of tuna is an asset that cannot be disregarded. The maternal isotopic signatures may be related to larval growth and condition variability, as well as to the origin of maternal feeding grounds.

\section{Post-flexion discrimination factors}

Field SIA studies on the trophic ecology on wild ABFT larvae are scarce (Laiz-Carrión et al. 2014, 2015). To understand early life trophodynamics more comprehensively, experimental research is needed. To interpret field data, field-based estimates of stable isotopes require experimental measurements of discrimination factors under laboratory-controlled conditions during the different ontogenic stages. The post-flexion larvae have the characteristics of an early juvenile. These have the necessary natatory and visual capacities to predate efficiently. Furthermore, ABFT larvae also show a precocious development of the digestive sys- 
tem that allows them to undergo the early diet shift to piscivory and contribute to their rapid somatic growth (Miyashita et al. 2001, Reglero et al. 2014, Yúfera et al. 2014).

Faster larval growth occurs when larvae are fed with protein-enriched sources with high $\delta^{15} \mathrm{~N}$ values under aquaculture conditions (Gamboa-Delgado et al. 2008, Tanaka et al. 2014). In field-based isotopic experiences, faster growth in larvae of $A$. rochei and $E$. encrasicolus showing higher $\delta^{15} \mathrm{~N}$ values has also been observed (Laiz-Carrión et al. 2013, Quintanilla et al. 2015). Higher $\delta^{15} \mathrm{~N}$ values in field post-flexion ABFT larvae indicated a greater feeding selectivity (Laiz-Carrión et al. 2015). Our results showed much higher $\delta^{15} \mathrm{~N}$ values in reared post-flexion larvae. These values do not reflect those observed in natural populations, where fast growth rates of captive fish can potentially result in the decrease in the discrimination factor $\left(\Delta^{15} \mathrm{~N}\right)(\mathrm{Gam}-$ boa-Delgado et al. 2008, Varela et al. 2011).

The estimated value of the nitrogen isotopic discrimination factor $(0.4 \%$ ) was lower than that reported by Varela et al. (2011) in ABFT juveniles (1.64\%o). The isotopic discrimination factor is lower in the first stages of development due to the high growth rates, which can cause changes in the $\delta^{13} \mathrm{C}$ and $\delta^{15} \mathrm{~N}$ values needed for tissue growth (Gamboa-Delgado et al. 2008). Howev$\mathrm{er}$, the isotopic discrimination factor of $\Delta^{13} \mathrm{C}$ could not be calculated because this stable isotope did not reach isotopic steady state with its prey. Therefore, we can assume that carbon requires more time to be integrated in larval tissues, as observed in other fish species (Gamboa-Delgado et al. 2008, Kiyoko et al. 2008).

\section{Estimation of nitrogen turnover rate and half times}

Short tissue half-times are common for nitrogen in early life stages of fish (2.8-5.2 d) (Vander Zanden and Rasmussen 2001). Tissues of fast-growing animals exhibit shorter half-times $\left(t_{50}\right)$ for nitrogen than slow-growing animals (MacAvoy et al. 2005), due to the fast growth rates characteristic of early life stages. The nitrogen isotopic changes observed in larvae can be attributed to tissue accretion and not to tissue metabolic turnover, contrary to what has been observed in adult organisms (Martínez del Río et al. 2009, Le Vay and Gamboa-Delgado 2011).

Since the carbon isotope did not reach the steady state between the larvae and its diet, it was not possible to estimate the turnover rates for carbon.

The results of this study examining the effects of diet composition, developmental stage, growth rates on stable isotope signatures represent the first data set that can be used to estimate the discrimination factors of the larval developmental stages of ABFT. These results will therefore be of broad relevance for future trophic field studies facilitating to the interpretation stable isotope data from field-captured larval specimens. In addition, the possibility of estimating maternal isotopic signatures from eggs and pre-flexion larvae opens research expectations which may relate maternal trophic levels with early larval growth potential.

\section{ACKNOWLEDGEMENTS}

The authors wish to thank Caladeros del Mediterráneo, who provided ABFT eggs. We would also like to thank the technicians from the culture facilities of the Aquaculture Experimental plant in Mazarrón, Murcia (IEO). This work was supported by the grant ATAME CTM2011-29525-C04-02 funded by the Spanish Ministry of Economy and Competitiveness. Amaya Uriarte was the recipient of an FPI-IEO 2011/03 pre-doctoral fellowship (Spanish Institute of Oceanography).

\section{REFERENCES}

Alemany F., Quintanilla L., Velez-Belchí P., et al. 2010. Characterization of the spawning habitat of Atlantic bluefin tuna and related species in the Balearic Sea (western Mediterranean). Prog. Oceanogr. 86: 21-38. http://dx.doi.org/10.1016/j.pocean.2010.04.014

Anderson J.T. 1988. A review of size dependent survival during prerecruit stages of fishes in relation to recruitment. J. Northw. Atl. Fish. Sci. 8: 55-66.

Bode A., Álvarez-Ossorio M.T., Cunha M.E., et al. 2007. Stable nitrogen isotope studies of the pelagic food web on the Atlantic shelf of the Iberian Peninsula. Prog. Oceanogr. 74: 115-131. http://dx.doi.org/10.1016/j.pocean.2007.04.005

Block B.A., Teo S.L.H., Walli A., et al. 2005. Electronic tagging and population structure of Atlantic bluefin tuna. Nature 434: 1121-1127. http://dx.doi.org/10.1038/nature03463

Caut S., Angulo E., Courchamp F. 2009. Variation in discrimination factors $\left(\Delta^{15} \mathrm{~N}\right.$ and $\left.\Delta^{13} \mathrm{C}\right)$ : the effect of diet isotopic values and applications for diet reconstruction. J. Appl. Ecol. 46: 443-453. http://dx.doi.org/10.1111/j.1365-2664.2009.01620.x

Catalan I.A., Tejedor A., Alemany F., et al. 2011. Trophic ecology of Atlantic bluefin tuna Thunnus thynnus larvae. J. Fish Biol. 78: $1545-1560$ http://dx.doi.org/10.1111/j.1095-8649.2011.02960.x

Costalago D., Navarro J., Alvarez-Calleja I., et al. 2012. Ontogenic and seasonal changes in the feeding habits and trophic levels of two small pelagic fish species. Mar. Ecol. Prog. Ser. 460: $169-181$. http://dx.doi.org/10.3354/meps09751

Cushing D. 1990. Plankton production and year-class strength in fish population: an update of the match/mismatch hypothesis. Adv. Mar. Biol. 26: 249-293. http://dx.doi.org/10.1016/S0065-2881(08)60202-3

De la Gándara F., Mylonas C.C., Covès D., et al. (eds). 2012. SELFDOTT Final Report, 46 pp. http://hdl.handle.net/10508/1119.

DeNiro M.J., Epstein S. 1978. Influence of diet on the distribution of carbon isotopes in animals. Geochim. Cosmochim. Acta 42: 495-506.

http://dx.doi.org/10.1016/0016-7037(78)90199-0

DeNiro M.J., Epstein S. 1981. Influence of diet on the distribution of nitrogen isotopes in animals. Geochim. Cosmochim. Acta 45: 341-351. http://dx.doi.org/10.1016/0016-7037(81)90244-1

Estrada J.A., Lutcavage M., Thorrold S.R. 2005. Diet and trophic position of Atlantic bluefin tuna (Thunnus thynnus) inferred from stable carbon and nitrogen isotope analysis. Mar. Biol. 147: 37-45. http://dx.doi.org/10.1007/s00227-004-1541-1

Fortier L., Leggett W. 1985. A drift study of larval fish survival. Mar. Ecol. Prog. Ser. 25: 245-257. http://dx.doi.org/10.3354/meps025245

Fromentin J.M., Powers J.E. 2005. Atlantic bluefin tuna: population dynamics, ecology, fisheries and management. Fish. Fish. 6: 281-306. http://dx.doi.org/10.1111/j.1467-2979.2005.00197.x

Gamboa-Delgado J., Cañavate J.P., Zerolo R., et al. 2008. Natural carbon stable isotope ratios as indicators of the relative contribution of live and inert diets to growth in larval Senegalese sole (Solea senegalensis). Aquaculture 280: 190-197. http://dx.doi.org/10.1016/j.aquaculture.2008.04.036

Gannes L.Z., O'Brien D.M., del Rio C.M. 1997. Stable isotopes in animal ecology: assumptions, caveats, and a call for more 
laboratory experiments. Ecology 78: 1271-1276. http://dx.doi.org/10.1890/0012-9658(1997)078[1271:SIIAEA] 2.0. $\mathrm{CO} ; 2$

García A., Cortés D., Quintanilla L., et al. 2004. Shrinkage effects on sardine larvae (Sardina pilchardus) conserved by ethanol and liquid nitrogen. Rapp. Comm. Int. Mer. Médit. 37: 360.

García A., Cortés D., Ramírez T., et al. 2006. First data on growth and nucleic acid and protein content of field-captured Mediterranean bluefin (Thunnus thynnus) and albacore (Thunnus alalunga) tuna larvae: a comparative study. Sci. Mar. 70S2: 67-78.

García A., Cortés D., Quintanilla J., et al. 2013. Climate-induced environmental conditions influencing interannual variability of Mediterranean bluefin (Thunnus thynnus) larval growth. Fish. Oceanogr. 22: 273-287. http://dx.doi.org/10.1111/fog. 12021

Green B.S., McCormick M.I. 2005. Maternal and paternal effects determine size, growth and performance in larvae of a tropical reef fish. Mar. Ecol. Prog. Ser. 289: 263-272. http://dx.doi.org/10.3354/meps289263

Hesslein R.H., Hallard K.A., Ramlal P. 1993. Replacement of sulfur, carbon, and nitrogen in tissue of growing broad whitefish (Coregonus nasus) in response to a change in diet traced by $\delta^{34} \mathrm{~S}, \delta^{13} \mathrm{C}$, and $\delta^{15}$ N. Can. J. Fish. Aquat. Sci. 50: 2071-2076. http://dx.doi.org/10.1139/f93-230

Hjort J. 1914. Fluctuations in the great fisheries of Northern Europe viewed in the light of biological research. Rapp. P.-v. Reun. Cons. Int. Explor. Mer 160: 1-228.

Hobson K.A. 1999. Tracing origins and migration of wildlife using stable isotopes: a review. Oecologia 120: 314-326. http://dx.doi.org/10.1007/s004420050865

Hobson K.A., Welch H.E. 1992. Determination of trophic relationships within a high Artic marine food web using $\delta^{13} \mathrm{C}$ and $\delta^{15} \mathrm{~N}$ analysis. Mar. Ecol. Prog. Ser. 84: 9-18. http://dx.doi.org/10.3354/meps084009

Hoffman J.C., Cotter A.M., Peterson G.S., et al. 2011. Rapid stable isotope turnover of larval fish in a Lake Superior coastal wetland: Implications for diet and life history studies. Aquat. Ecosyst. Health 14: 403-413 http://dx.doi.org/10.1080/14634988.2011.628212

Hoie H., Folkvord A., Johannessen A. 1999. Maternal, paternal and temperature effects on otolith size of young herring (Clupea harengus L.) larvae. J. Exp. Mar. Biol. Ecol. 234: 167-184. http://dx doi.org/10.1016/S0022-0981(98)00154-3

Houde E.D. 1987. Fish early life dynamics and recruitment variability. Am. Fish. Soc. Symp. 2: 17-29.

ICCAT 2005. Recommendation by ICCAT to establish a multiannual recovery plan for bluefin tuna in the eastern Atlantic and Mediterranean. ICCAT, 06-05,14 pp.

Itoh T., Shiina S., Tsuji F., et al. 2000. Otolith daily increment formation in laboratory reared larval and juvenile bluefin tuna Thunnus thynnus. Fish. Sci. 66: 834-839 http://dx.doi.org/10.1046/j.1444-2906.2000.00135.x

Jardine T.D., Chernoff E., Curry R.A. 2008. Maternal transfer of carbon and nitrogen to progeny of sea-run and resident brook charr (Salvelinus fontinalis). Can. J. Fish. Aquat. Sci. 65: 2201-2210 http://dx.doi.org/10.1139/F08-132

Kaji T. 2003. Bluefin tuna larval rearing and development- state of the art. Cahier Options Méditerranéennes 60: 85-89.

Kaji T., Oka M., Takeuchi H., et al. 1999. Development of growth hormone cells of laboratory reared yellowfin tuna Thunnus albacores larvae and early juveniles. Fish. Sci. 65: 583-587.

Kiyoko R., Ducatti C., Dalton J.C., et al. 2008. Stable carbon $\left(\delta^{13} C\right)$ and nitrogen $\left(\delta^{15} \mathrm{~N}\right)$ isotopes as natural indicators of live and dry food in Piaractus mesopotamicus (Holmberg, 1887) larval tissue. Aquac. Res. 39: 370-381. http://dx.doi.org/10.1111/j.1365-2109.2007.01760.x

Laiz-Carrión R., Quintanilla J.M., Mercado J.M., et al. 2011. Combined study of daily growth variability and nitrogen-carbon isotopic signature analysis of schooling Sardina pilchardus larvae. J. Fish Biol. 79: 896-914. http://dx.doi.org/10.1111/j.1095-8649.2011.03048.x

Laiz-Carrión R., Quintanilla J.M., Torres A.P., et al. 2013. Hydrographic patterns conditioning variable trophic pathways and early life dynamics of bullet tuna Auxis rochei larvae in the Balearic Sea. Mar. Ecol. Prog. Ser. 475: 203-212. http://dx.doi.org/10.3354/meps10108

Laiz-Carrión R., Gerard T., Uriarte A., et al. 2014. Larval bluefin tuna (Thunnus thynnus) trophodynamics from Balearic Sea (WM) and Gulf of Mexico spawning ecosystems by stable iso- tope. ICCAT SCRS/2014/103.

Laiz-Carrión R., Gerard. T., Uriarte A., et al. 2015. Trophic ecology of Atlantic bluefin tuna (Thunnus thynnus) larvae from the Gulf of Mexico and NW Mediterranean spawning grounds: a comparative stable isotope study. PLoS One 10: e0138638. http://dx.doi.org/10.1371/journal.pone.0138638

Le Bourg B., Kiszka J., Bustamante P. 2014. Mother-embryo isotope $\left({ }^{15} \mathrm{~N},{ }^{13} \mathrm{C}\right)$ fractionation and fractionation and mercury $(\mathrm{Hg})$ transfer in aplacental deep-sea sharks. J. Fish Biol. 84: 1574-1581. http://dx.doi.org/10.1111/jfb.12357

Le Vay L., Gamboa-Delgado J. 2011. Naturally-occurring stable isotopes as direct measures of larval feeding efficiency, nutrient incorporation and turnover. Aquaculture 315: 95-103. http://dx.doi.org/10.1016/j.aquaculture.2010.03.033

Logan J.M., Jardine T.D., Miller T.J., et al. 2008. Lipid corrections in carbon and nitrogen stable isotope analyses: comparison of chemical extraction and modelling methods. J. Anim. Ecol. 77: 838-846.

http://dx.doi.org/10.1111/j.1365-2656.2008.01394.x

Logan J.M., Rodríguez-Marín E., Goñi N., et al. 2010. Diet of young Atlantic bluefin tuna (Thunnus thynnus) in eastern and western Atlantic foraging grounds. Mar. Biol. 158: 73-85. http://dx.doi.org/10.1007/s00227-010-1543-0

Llopiz J.K., Richardson D.E., Shiroza A., et al. 2010. Distinctions in the diets and distributions of larval tunas and the important role of appendicularians. Limnol. Oceanogr. 55(3): 983-996. http://dx.doi.org/10.4319/lo.2010.55.3.0983

Llopiz J.K., Muhling B.A., Lamkin J.T. 2014. Feeding dynamics of Atlantic bluefin tuna (Thunnus thynnus) larvae in the Gulf of Mexico. ICCAT SCRS/2014/173.

MacAvoy S.E., Arneson L.S., Bassett E. 2005. Growth versus metabolic tissue replacement in mouse tissues determined by stable carbon and nitrogen isotope analysis. Can. J. Zool. 83: 631-641. http://dx.doi.org/10.1139/z05-038

MacKenzie B.R., Mosegaard H., Rosenberg A.A. 2009. Impending collapse of bluefin tuna in the northeast Atlantic and Mediterranean. Conser. Let. 2: 25-34. http://dx.doi.org/10.1111/j.1755-263X.2008.00039.x

Madigan D.J., Litvin S.Y., Popp B.N., et al. 2012. Tissue turnover rates and isotopic trophic discrimination factors in the endothermic teleost, Pacific bluefin tuna (Thunnus orientalis) PLoS One 7: e49220.

http://dx.doi.org/10.1371/journal.pone.0049220

Marteinsdottir G., Steinarsson A. 1998. Maternal influence on the size and viability of Icelandie cod (Gadus morhua L.) by incluing age diversity of spawners. Can. J. Fish. Aquat. Sci. 55: 1372-1377. http://dx.doi.org/10.1139/f98-035

Martínez del Rio C., Wolf N., Carleton S.A., et al. 2009. Isotopic ecology ten years after a call for more laboratory experiments. Biol. Rev. 84: 91-111. http://dx.doi.org/10.1111/j.1469-185X.2008.00064.x

Mather F.J., Mason J.M., Jones A.C. 1995. Historical document: life history and fisheries of Atlantic bluefin tuna. U.S. Department of Commerce, NOAA Technical Memorandum, NMFS-SEFSC $370,165 \mathrm{pp}$

McMeans B.C., Olin J.A., Benz W. 2009. Stable-isotope comparisons between embryos and mothers of a placentatrophic shark species. J. Fish. Biol. 75: 2464-2474. http://dx.doi.org/10.1111/j.1095-8649.2009.02402.x

Minagawa M., Wada E. 1984. Stepwise enrichment of ${ }^{15} \mathrm{~N}$ along food chain: further evidence and the relation between $\delta^{15} \mathrm{~N}$ and animal age. Geochim. Cosmochim. Acta 48: 1135-1140. http://dx.doi.org/10.1016/0016-7037(84)90204-7

Miyashita S., Sawada Y., Okada T., et al. 2001. Morphological development and growth of laboratory-reared larval and juvenile Thunnus orientalis (Pisces: Scombridae). Fish. Bull. 99: 601-616.

Monteleone D.M., Houde E.D. 1990. Influence of maternal size on survival and growth of striped bass, Morone saxatilis, eggs and larvae. J. Exp. Mar. Biol. Ecol. 140: 1-11 http://dx.doi.org/10.1016/0022-0981(90)90076-O

Ortega A., Seoka M., Belmonte A., et al. 2011. Cultivo larvario de atún rojo (Thunnus thynnus) en el Centro Oceanográfico de Murcia (IEO). XIII Congreso Nacional de Acuicultura. Castelldefels (Barcelona) España.

Pepin P., Dower J.F. 2007. Variability in the trophic position of larval fish in a coastal pelagic ecosystem based on stable isotope analysis. J. Plankton Res. 29: 727-737. 
http://dx.doi.org/10.1093/plankt/fbm052

Pepin P., Dominique R., Bouchard C., et al. 2014. Once upon a larva: revisiting the relationship between feeding success and growth in fish larvae. ICES J. Mar. Sci. 72: 359-373. http://dx.doi.org/10.1093/icesjms/fsu201

Perez K.O., Fuiman L.A. 2015. Maternal diet and larval diet influence survival skills of larval red drum Sciaenops ocellatus. J. Fish Biol. 86: 1286-1304. http://dx.doi.org/10.1111/jfb.12637

Peterson B.J., Fry B. 1987. Stable isotopes in ecosystem studies. Ann. Rev. Ecol. Syst. 18: 293-320. http://dx.doi.org/10.1146/annurev es.18.110187.001453

Post D.M. 2002. Using stable isotopes to estimate trophic position models, methods, and assumptions. Ecology 83: 703-718. http://dx.doi.org/10.1890/0012-9658(2002)083[0703:USITET] 2.0.CO;2

Quintanilla J.M., Laiz-Carrion R., Uriarte A., et al. 2015. Influence of trophic pathways on daily growth patterns of western Mediterranean anchovy Engraulis encrasicolus larvae. Mar. Ecol. Prog. Ser. 531: 263-275. http://dx.doi.org/10.3354/meps 11312

Reglero P., Urtizberea A., Torres A., et al. 2011. Cannibalism among size classes of larvae may be a substantial mortality component in tuna. Mar. Ecol. Prog. Ser. 433: 205-219. http://dx.doi.org/10.3354/meps09187

Reglero P., Ortega A., Blanco E., et al. 2014. Size-related differences in growth and survival in piscivorous fish larvae fed different prey types. Aquaculture 433: 94-101. http://dx.doi.org/10.1016/j. aquaculture 2014.05.050

Rooker J.R., Bremer A.J.R., Block B.A., et al. 2007. Life history and stock structure of Atlantic bluefin tuna (Thunnus thynnus). Rev. Fish. Sci. 15: 265-310. http://dx.doi.org/10.1080/10641260701484135

Satoh K., Tanaka Y., Masujima M., et al. 2013. Relationship between the growth and survival of larval Pacific bluefin tuna, Thunnus orientalis. Mar. Biol. 160: 691-702. http://dx.doi.org/10.1007/s00227-012-2124-1

Suzuki Z., Kimoto A., Sakai O. 2013. Note on the strong 2003 yearclass that appeared in the Atlantic bluefin fisheries. Collect. Vol. Sci. Pap. ICCAT 69: 229-234.

Swain P., Nayak S.K. 2009. Role of maternally derived immunity in fish. Fish Shellfish Immun. 27: 89-99. http://dx.doi.org/10.1016/j.fsi.2009.04.008
Sweeting C.J., Barry J.T., Polunin N.V.C., et al. 2007a. Effects of body size and environment on diet-tissue $\delta^{15} \mathrm{~N}$ fractionation in fishes. J. Exp. Mar. Biol. Ecol. 340: 1-10 http://dx.doi.org/10.1016/j.jembe.2006.07.023

Sweeting C. J., Barry J.T., Polunin N. V.C., et al. 2007b. Effects of body size and environment on diet-tissue $\delta^{13} \mathrm{C}$ fractionation in fishes. J. Exp. Mar. Biol. Ecol. 352: 165-176. http.//dx doi.org/10.1016/j jembe 2007.07 .007

Tanaka Y., Satoh K., Iwahashi M., et al. 2006. Growth-dependent recruitment of Pacific bluefin tuna Thunnus orientalis in the northwestern Pacific Ocean. Mar. Ecol. Prog. Ser. 319: 225-235. http://dx.doi.org/10.3354/meps319225

Tanaka Y., Minami H., Ishihi Y., et al. 2010. Prey utilization by hatchery-reared Pacific bluefin tuna larvae in mass culture tank estimated using stable isotope analysis, with special reference to their growth variation. Aquac. Sci. 58: 501-508.

Tanaka Y., Minami. H., Ishihi Y., et al. 2014. Relationship between prey utilization and growth variation in hatchery-reared Pacific bluefin tuna, Thunnus orientalis (Temminck et Schlegel), larvae estimated using nitrogen stable isotope analysis. Aquac. Res. 45: $537-545$. http://dx.doi.org/10.1111/j.1365-2109.2012.03258.x

Vander Zanden M.J., Rasmussn J.B. 2001. Variation in $\delta^{15} \mathrm{~N}$ and $\delta^{13} \mathrm{C}$ trophic fractionation: Implications for aquatic food web. Limnol. Oceanogr. 44: 2061-2066. http://dx.doi.org/10.4319/1o.2001.46.8.2061

Varela J.L., Larrañaga A., Medina A. 2011. Prey-muscle carbon and nitrogen stable-isotope discrimination factors in Atlantic bluefin tuna (Thunnus thynnus). J. Exp. Mar. Biol. Ecol. 406: 21-28. http://dx.doi.org/10.1016/j.jembe.2011.06.010

Vaudo J.J., Matich P., Heithaus M.R. 2010. Mother-offspring isotope fractionation in two species of placentatrophic sharks. J. Fish Biol. 77: 1724-1727. http://dx.doi.org/10.1111/j.1095-8649.2010.02813.x

Wolf N., Carleton S.A., Martinez del Rio C. 2009. Ten years of experimental animal isotopic ecology. SIA in animal ecology. Funct. Ecol. 23: 17-26. http://dx.doi.org/10.1111/j.1365-2435.2009.01529.x

Yúfera M., Ortiz-Delgado J.B., Hoffman T., et al. 2014. Organogenesis of digestive system, visual system and other structures in Atlantic bluefin tuna (Thunnus thynnus) larvae reared with copepods in mesocosm system. Aquaculture 426-427: 126-137. http://dx.doi.org/10.1016/j.aquaculture.2014.01.031 